\title{
Release of Arsenic from Arsenic Removal Water Filter Sludge in Soil and Its Uptake by Red Amaranth
}

\author{
Sajal Roy ${ }^{1}$, Shah Muhammad Imamul Huq ${ }^{2}$, Md. Abul Kashem ${ }^{1 *}$, Khan Towhid Osman ${ }^{1}$ \\ ${ }^{1}$ Department of Soil Science, University of Chittagong, Chittagong, Bangladesh; ${ }^{2}$ Bangladesh-Australia Centre for Environmental \\ Research, Department of Soil, Water and Environment, University of Dhaka, Dhaka, Bangladesh. \\ Email: *kashem00@yahoo.com
}

Received September $19^{\text {th }}, 2013$; revised October $19^{\text {th }}, 2013$; accepted October $26^{\text {th }}, 2013$

Copyright (C 2013 Sajal Roy et al. This is an open access article distributed under the Creative Commons Attribution License, which permits unrestricted use, distribution, and reproduction in any medium, provided the original work is properly cited.

\begin{abstract}
There is a major concern among scientists over the elevated levels of arsenic (As) in drinking water in Bangladesh and some parts of India. Investigating the release of As from water filter sludge in soil and its uptake by plants may provide information about the management of As contaminated filter sludge. In this macrocosm study, iron based sludge containing granular ferric hydroxide (GFH) was mixed with air dried silt loam surface soil at rate of 0 (control, no sludge), 1.5 and $2.5 \mathrm{t}^{\mathrm{h}} \mathrm{ha}^{-1}$ and red amaranth (Amaranthus tricolor L.) plants were grown for 45 days. Addition of filter sludge did not affect the height, fresh weight and dry matter yield of amaranth. However, the highest concentration of As and Fe were found both in shoots and roots of amaranth grown in the pot of the highest rate of sludge treated soil. The concentration of As, Fe and S was higher in the roots than that in the shoots of Amaranth. Translocation of As, $\mathrm{S}$ and Fe increased with the rates of sludge application. Elevated concentration of As in sludge treated plants is a sign of environmental hazard and should be taken into consideration.
\end{abstract}

Keywords: Arsenic; Accumulation; Concentration; Red Amaranth; Translocation

\section{Introduction}

Arsenic (As) contamination through soil-water-plant are of international concern due to widespread distribution in South East Asia, namely, Bangladesh and its potential health risks on human and animals [1]. Arsenic contamination through drinking water and other ways including arsenic contaminated foods poses threat to human health. Arsenic intake in humans from rice and cattle could be potentially hazardous [2]. In arsenic affected areas, accumulation of arsenic in soils and plants may pose a threat to general food security and in the long-term the sustainability of agriculture [3]. Arsenic contaminated groundwater when used for irrigation, led to the accumulation of arsenic in soil and the eventual exposure of the food chain through plant uptake and animal consumption [4]. Increased arsenic concentrations in rice grain and straw may further enhance human arsenic intake, as direct source via grain or as secondary source through feeding livestock producing meat or milk [3]. The main source of air and soil contamination with arsenic compounds is the mining of coal and oil as well as

\footnotetext{
${ }^{*}$ Corresponding author.
}

mining and metallurgy of non-ferrous metals [5]. Contamination of drinking water (groundwater) arises from arsenic-rich rocks [6]. At present, different media such as granular ferric hydroxide, activated alumina, etc. is used for the removal of arsenic from drinking water. The disposal of the sludge from As filter media has become a great concern for the environmental scientists. Once the sludge is disposed of into the soil, it may act as a source of soil contamination with arsenic and other toxic elements [7]. The release of arsenic from arsenic removal water filter sludge could enhance arsenic bioavailability to plants due to mobilization of As into the soil solution. Therefore, the objective of this study was to investigate the extent of arsenic release from arsenic removal water filter sludge and its uptake by amaranth plant.

\section{Materials and Methods}

For pot culture experiment, bulk soil samples were collected from upper surface $(\sim 15 \mathrm{~cm})$ of an agricultural land. After collection, the soil samples were air dried for 5 days $\left(-35^{\circ} \mathrm{C}\right)$. Visible roots and debris were removed and larger aggregates were broken down by using a 
wooden hammer and mixed thoroughly to make the samples homogeneous. For the purpose of pot culture, the soil samples were sieved through a $5 \mathrm{~mm}$ sieve. Moist soil equivalent to $4 \mathrm{~kg}$ dry mass was placed in earthen pots (30 cm height and $25 \mathrm{~cm}$ diameter) after mixing with arsenic removal water filter sludge at levels of $0,1.5$ and $2.5 \mathrm{t} \cdot \mathrm{ha}^{-1}$ which provided $0,0.41$ and $0.68 \mathrm{mg} \mathrm{As}$ $\mathrm{kg}^{-1}$ soil, respectively. A portion of the $5 \mathrm{~mm}$ sieved sample was further screened through a $2 \mathrm{~mm}$ sieve which was used for various physical and chemical analyses. The pots were arranged in a completely randomized design with three replications. Each pot received a basal dose of N-P-K (137-32-70 $\left.\mathrm{kg} \cdot \mathrm{ha}^{-1}\right)$ in the form of urea, muriate of potash (MP) and triple super phosphate (TSP). The sludge amended soil pots were allowed to react for 15 days at moist condition. Afterwards, 15 red amaranth seeds were sown in each pot. After 10 days of emergence 5 healthy seedlings were kept to grow in each pot. Plants were watered at field capacity. The plants were harvested by uprooting at 45 days of growth.

After harvest, the plants were washed several times with tap water and finally with distilled water. Then the plants were wrapped between towels. The plant samples were separated into roots and shoots. The fresh weights of the collected plant samples were recorded. Then the samples were first air-dried and then oven-dried at $65^{\circ} \mathrm{C}$ for 72 hours to ensure complete removal of moisture. From oven dry weight the percent moisture content was determined. The samples were ground with an electrical grinder and sieved through a $0.2 \mathrm{~mm}$ sieve. Oven dry samples were used for various chemical analyses.

Soil $\mathrm{pH}$ was determined from 1:2.5 soil-water suspension by a $\mathrm{pH}$ meter. Available $\mathrm{K}$ was determined by flame analyzer after extracting the soil sample with $1 \mathrm{~N}$ ammonium acetate at $\mathrm{pH}$ 7. Available $\mathrm{P}$ was determined by ascorbic acid blue color method after extracting the soil with $0.5 \mathrm{M} \mathrm{NaHCO}_{3}$ solution ( $\mathrm{pH}$ 8.5). Total and available $\mathrm{N}$ in soil were determined by Micro-Kjeldahl method [8]. For the determination of available $\mathrm{N}$, the soil sample was extracted with $1 \mathrm{~N} \mathrm{KCl}$ solution at soil: extractant ratio of $1: 10$. For determination of total $\mathrm{N}$, the soil sample was digested with concentrated $\mathrm{H}_{2} \mathrm{SO}_{4}$. For the determination of total As and Fe, the soil samples were digested with aqua regia $\left(\mathrm{HNO}_{3}: \mathrm{HCl}=1: 3\right)$. The plant samples were digested with $\mathrm{HNO}_{3}$ for the determination of total As, $\mathrm{P}, \mathrm{S}$, and Fe. Total $\mathrm{P}$ and $\mathrm{S}$ were determined by procedures as followed by Huq and Alam [8]. The total $\mathrm{P}$ in plants was determined by spectrophotometer at a wavelength of $490 \mathrm{~nm}$ by developing yellow color with vanadomolybdate. The total S was determined by turbidimetric method using Tween- 80 . The reading was taken by spectrophotometer at $420 \mathrm{~nm}$. The total arsenic contents in soil and plant tissues were determined by a hydride generation-atomic absorption spectrometer (HGAAS) [9]. Total Fe contents in soil and plants were determined by atomic absorption spectrometer. The concentrations of all elements in plant were calculated on oven dry basis. Translocation percentage was determined as $($ shoot $/$ total $) \times 100$. All data were processed and statistically analyzed by using Microsoft Excel (Microsoft Office 2010) and SPSS (version 16) Packages.

\section{Results and Discussion}

The $\mathrm{pH}$ of the soil was slightly acid (6.6). The soil was silt loam in texture containing $19 \%$ clay, $61 \%$ silt and $20 \%$ sand. The contents of available N, P and K were very low. The available $\mathrm{N}, \mathrm{P}$, and $\mathrm{K}$ contents were 51.10 $\mathrm{mg} \cdot \mathrm{kg}^{-1}, 21 \mathrm{mg} \cdot \mathrm{kg}^{-1}$ and $70 \mathrm{mg} \cdot \mathrm{kg}^{-1}$ soil, respectively. Total As content of the experimental soil was 2.58 $\mathrm{mg} \cdot \mathrm{kg}^{-1}$. The concentration of As in Bangladesh soil may reach $80 \mathrm{mg} \cdot \mathrm{kg}^{-1}$ in places where contaminated water was used for irrigation with an average value below $10 \mathrm{mg} \cdot \mathrm{kg}^{-1}$ [10]. The background Fe concentration of the soil was $1.67 \%$. The sludge contained high content of As $\left(611 \mathrm{mg} \cdot \mathrm{kg}^{-1}\right)$

Growth parameters were less affected by the application of As containing filter sludge in the soil. The mean height of amaranth plant was 24, 25 and $27 \mathrm{~cm}$ respectively in the control, 1.5 and $2.5 \mathrm{t} \cdot \mathrm{ha}^{-1}$ rate. The results showed that fresh weight and dry matter yield of amaranth plant increased with the rates of sludge application to the soils (Figure 1). This could be due to the nutrients, particularly iron and other micronutrients released from the sludge into the growth media and became available to plants resulting enhanced growth. Similar to our results, [7] observed higher dry matter production of Ipomoea aquatic plants grown in the soils spiked with the granular iron sludge than the plants grown in the control soil pots. Roy et al. [11] found higher yield and mean height in sludge treated plants over control but less in As containing irrigated plants. Several scientists, on the other hand, reported lower yield and shorter height of plants with increasing As concentration in soil [12-14].

The concentrations of $\mathrm{As}, \mathrm{P}, \mathrm{S}$ and $\mathrm{Fe}$ in roots and shoots of plants grown in control and As spiked soils are shown in Table 1. It is clear from the table that the concentration of arsenic in roots and shoots increased with increased As in the growth media. In all cases, the roots contained more As than the shoots. Arsenic concentration in roots was $6,4.7$ and 4.9 folds greater than the concentration in the shoots at control, $1.5 \mathrm{t} \cdot \mathrm{ha}^{-1}$ and 2.5 $\mathrm{t} \cdot \mathrm{ha}^{-1}$ respectively. This indicates that As was mostly concentrated in roots. As is mostly concentrated in roots and subsequently translocate in plants in order of root $>$ shoot $>$ grain [15-17]. The higher concentration of As in roots may be due to the strong adsorption of anions to the root surface. The As anions (both arsenate and arsenite) rapidly adsorb to the root surface which lead to intense high concentration of As [13]. 


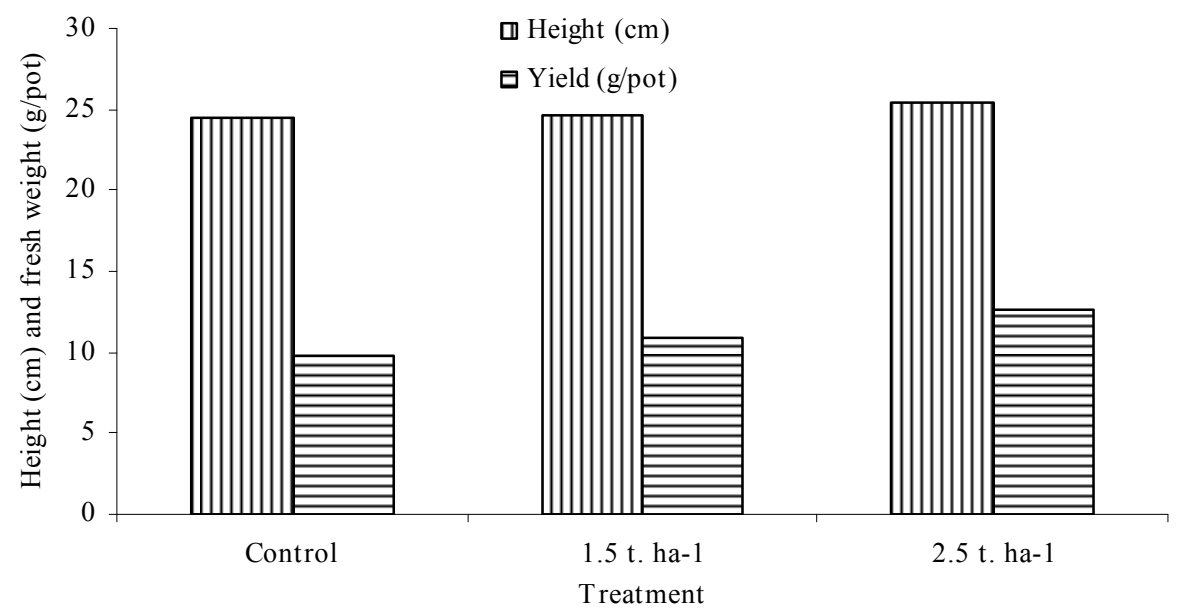

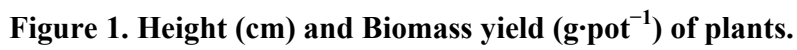

Table 1. Concentration of As $\left(\mathrm{mg}^{\circ} \mathrm{kg}^{-1}\right)$ and $\mathrm{P}, \mathrm{S}$ and Fe concentration (\%) in shoots and roots of dry plant tissue.

\begin{tabular}{|c|c|c|c|c|c|c|c|c|}
\hline \multirow{2}{*}{ Treatment } & \multicolumn{2}{|c|}{ As } & \multicolumn{2}{|c|}{$\mathbf{P}$} & \multicolumn{2}{|c|}{$\mathbf{S}$} & \multicolumn{2}{|c|}{$\mathrm{Fe}$} \\
\hline & Shoot & Root & Shoot & Root & Shoot & Root & Shoot & Root \\
\hline $\mathrm{C}$ & $0.045^{\mathrm{b}}$ & $0.275^{\mathrm{b}}$ & $0.612^{\mathrm{a}}$ & 0.515 & 0.018 & 0.029 & 0.139 & 0.369 \\
\hline $1.5 \mathrm{t} \cdot \mathrm{ha}^{-1}$ & $0.109^{\mathrm{a}}$ & $0.509^{\mathrm{a}}$ & $0.691^{\mathrm{a}}$ & 0.544 & 0.019 & 0.025 & 0.148 & 0.345 \\
\hline $2.5 \mathrm{t} \cdot \mathrm{ha}^{-1}$ & $0.110^{\mathrm{a}}$ & $0.536^{\mathrm{a}}$ & $0.768^{b}$ & 0.598 & 0.018 & 0.027 & 0.166 & 0.387 \\
\hline$P$ value & 0.041 & 0.021 & 0.035 & 0.596 & 0.953 & 0.683 & 0.078 & 0.836 \\
\hline
\end{tabular}

The concentration of $\mathrm{P}$ in shoots was found to be higher in As spiked soils. The concentration of $\mathrm{P}$ in shoots was $1.19,1.27$ and 1.28 -folds greater than the concentration in the roots at control, $1.5 \mathrm{t} \cdot \mathrm{ha}^{-1}$ and 2.5 $\mathrm{t} \cdot \mathrm{ha}^{-1}$ respectively.

It is widely accepted that arsenate and phosphate share the same uptake and transport pathways in higher plants, with the carriers having a greater affinity for As (V) [18]. In contrast, other evidence reveals that phosphate fertilization of paddy soils could therefore be possibilities for reducing the uptake of As (V) and As (III) in the rice plant [19], the same is true in our case where As concentration was lower and $\mathrm{P}$ concentration was higher in shoots and opposite was the case in roots irrespective of the treatments.

The concentration of $\mathrm{S}$ and $\mathrm{Fe}$ in shoots and roots of plants were not affected by the application of sludge application. However, in case of $\mathrm{Fe}$, the magnitude of $\mathrm{Fe}$ concentration in roots was more than 2 folds higher in roots than in shoots as did with As. Similar trend of Fe concentration in plant tissue were observed by other investigators $[7,11]$.

Total accumulation was calculated by multiplying the concentrations of As, P, S and Fe in the dry matter and the total dry matter produced (Figure 2). Maximum accumulation of As, $\mathrm{P}$ and $\mathrm{Fe}$ was found at application rate of $2.5 \mathrm{t} \cdot \mathrm{ha}^{-1}$. The accumulation As, $\mathrm{P}$ and $\mathrm{Fe}$ in plant was found in order of $2.5 \mathrm{t} \cdot \mathrm{ha}^{-1}>1.5 \mathrm{t} \cdot \mathrm{ha}^{-1}>$ control. The accumulation of $\mathrm{P}$ was 1.22 and 1.60 times higher in 1.5 $\mathrm{t} \cdot \mathrm{ha}^{-1}$ and $2.5 \mathrm{t} \cdot \mathrm{ha}^{-1}$ over control. The accumulation of As was 2.2 and 2.6 times higher in $1.5 \mathrm{t} \cdot \mathrm{ha}^{-1}$ and $2.5 \mathrm{t} \cdot \mathrm{ha}^{-1}$ over control. Similar results were found by other scientists $[7,11]$, where they observed that the concentration of As in both shoot and root increased in As spiked plants over control. However, little differences were found in the accumulation of $\mathrm{S}$ in plants under different treatments. Meharg and Macnair [20] reported that arsenate is taken up by the phosphate uptake system in plants. In well aerated condition, As might compete with $\mathrm{P}$ absorption, resulting in a decrease in the concentration of $\mathrm{P}$ in plant roots.

The accumulation of $\mathrm{Fe}$ was 1.2 and 1.4 times greater at $1.5 \mathrm{t} \cdot \mathrm{ha}^{-1}$ and $2.5 \mathrm{t} \cdot \mathrm{ha}^{-1}$ compared to control. The study showed that $\mathrm{Fe}$ accumulation increased in plant with the increase of As accumulation showing a synergy between As and Fe. Maximum accumulation of $\mathrm{Fe}$ in sludge treated plants indicates the release as well as the availability of $\mathrm{Fe}$ in soil. Iron based As removal water filter sludge releases $\mathrm{As}$ and $\mathrm{Fe}$ over time and make these available for plants to take up from soil $[7,11]$.

Figure 3 shows the percent translocation of As, P, S and Fe from root to shoot. The translocation of As, P, S and $\mathrm{Fe}$ was found higher in As treated plants. Maximum translocation of As and $\mathrm{S}$ was found at $1.5 \mathrm{t} \cdot \mathrm{ha}^{-1}$ rate. The translocations of As at 1.5 and $2.5 \mathrm{t} \cdot \mathrm{ha}^{-1}$ were 1.27 and 1.22-folds higher respectively over control. The 


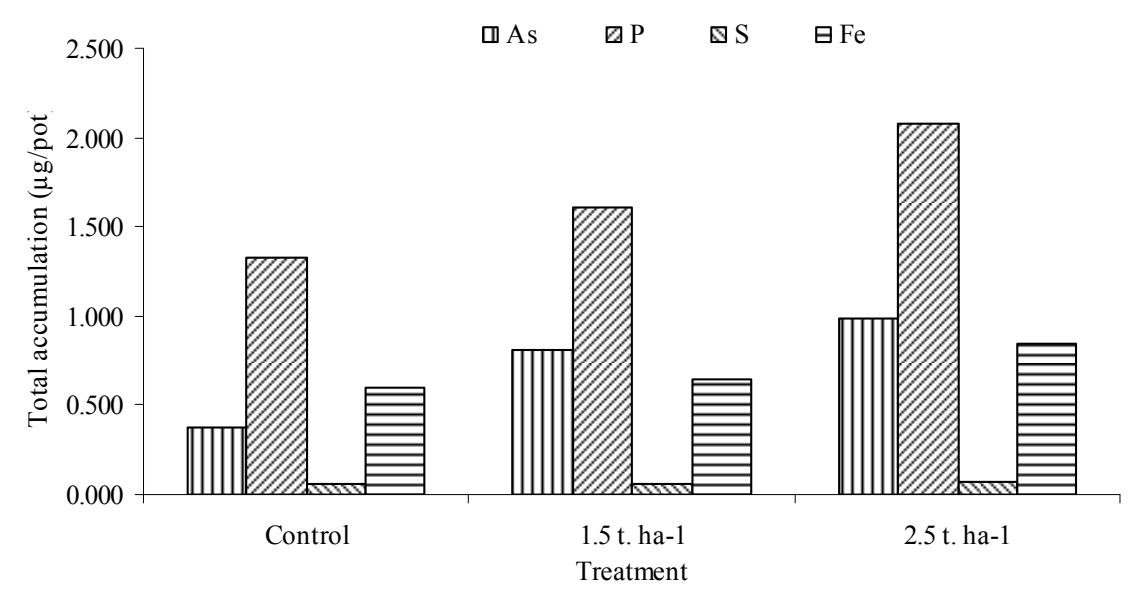

Figure 2. Accumulation ( $\mu \mathrm{g} / \mathrm{pot})$ of elements under different treatments.

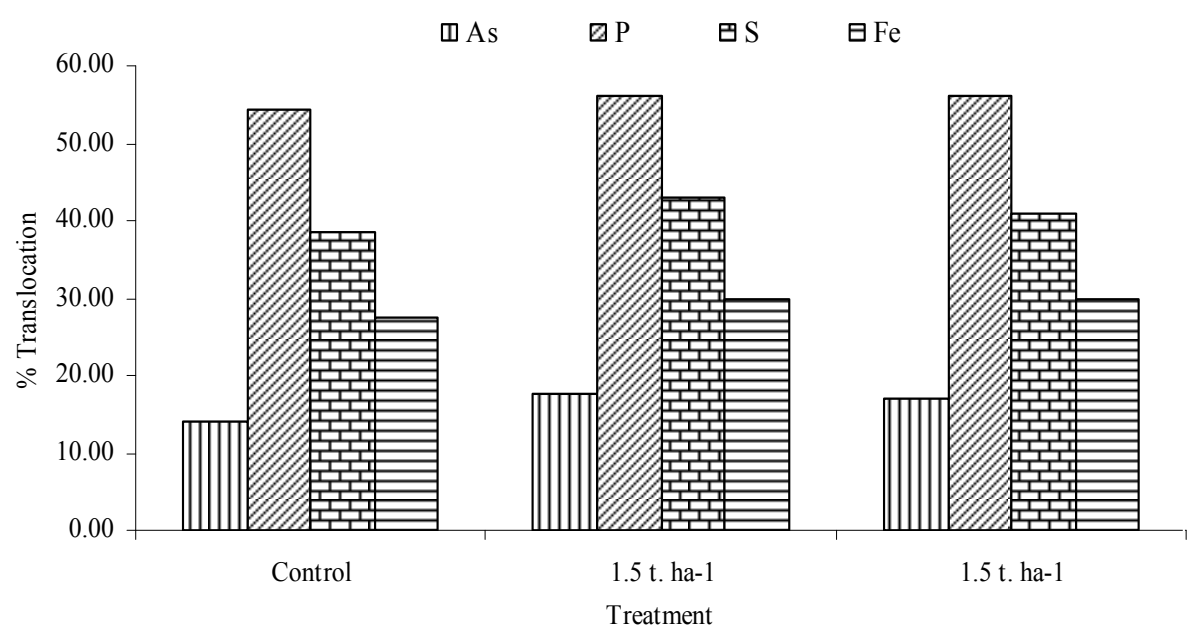

Figure 3. Translocation (\%) of elements in plants under different treatments.

translocation of $\mathrm{P}$ increased by 1.03 and 1.04 times at 1.5 and $2.5 \mathrm{t}^{-\mathrm{ha}^{-1}}$ rate. Molla et al. [21] observed increased translocation (\%) of $\mathrm{P}$ with increasing As toxicity. Percent translocation of $\mathrm{Fe}$ was almost same at 1.5 and 2.5 $\mathrm{t} \cdot \mathrm{ha}^{-1}$ rate which was 1.10 -folds higher over control. The concentration of $\mathrm{Fe}$ remains statistically constant in shoots but increases in the roots with increase in As treatment [22].

\section{Conclusion}

The toxicity of As from the release of sludge was not severe enough to cause environmental hazard. However, the release of As from the sludges over a long period might be a hazard for human as well as for animals in the future. So, the raw materials used for making As removing water filter should not be disposed of indiscriminately to the soil, particularly to the agricultural fields.

\section{REFERENCES}

[1] S. Rahaman, A. C. Sinha and D. Mukhopadhyay, "Effect of Water Regimes and Organic Matters on Transport of Arsenic in Summer Rice (Oryza sativa L.)," Journal of Environmental Sciences Vol. 23, No. 4, 2011, pp. 633639. http://dx.doi.org/10.1016/S1001-0742(10)60457-3

[2] M. A. Rahman, H. Hasegawa, M. M. Rahman, M. A. M. Miah and A. Tasmin, "Straight Head Disease of Rice (Oryza sativa L.) Induced by Arsenic Toxicity," Environmental and Experimental Botany, Vol. 62, No. 1, 2008, pp. 54-59.

http://dx.doi.org/10.1016/j.envexpbot.2007.07.016

[3] H. Brammer and P. Ravenscroft, "Arsenic in Groundwater: A Threat to Sustainable Agriculture in South and South-East Asia," Environment International, Vol. 35, No. 3, 2009, pp. 647-654. http://dx.doi.org/10.1016/j.envint.2008.10.004

[4] S. M. I. Huq and R. Naidu, "Arsenic in Ground Water and Contamination of the Food Chain: Bangladesh Scenario," In: Bundschuh, Bhattacharya and Chandrasekharam, Eds., Natural Arsenic in Ground Water: Occurrence, Remediation and Management, A. A. Balkema Publishers, New York, 2005, pp. 95-101.

[5] K. Ozna and J. Biernat, "The Occurrence of Arsenic in the Environment and Food," Roczniki Panstwowego Za- 
kadu Higieny, Vol. 59, 2008, pp. 19-31.

[6] S. Chakma, M. M. Rahman, P. Islam, M. A. Awal, U. K. Roy and M. R. Haq, "Arsenic in Rice and Rice Straw," The Bangladesh Veterinarian, Vol. 29, No. 1, 2012, pp. 1-6.

[7] S. M. I. Huq, L. Nesa, M. T. A. Chowdhury and J. C. Joardar, "Disposal of Arsenic Filter Sludge in Soil and Its Consequences," Environmental Science and Engineering, Vol. 5, No. 2, 2011, pp. 165-176.

[8] S. M. I. Huq and M. D. Alam, "A Handbook on Analyses of Soil, Plant, and Water," BACER-DU, University of Dhaka, Bangladesh, 2005, pp. 1-246.

[9] J. E. Portman and J. P. Riley, "Determination of Arsenic in Seawater, Marine Plants and Silicate and Carbonate Sediments," Analytica Chimica Acta, Vol. 31, 1964, pp. 509-519. http://dx.doi.org/10.1016/S0003-2670(00)88870-4

[10] S. M. I. Huq, A. Rahman, N. Sultana and R. Naidu, "Extent and Severity of Arsenic Contamination in Soils of Bangladesh," In: F. M. Ahmed, M. A. Ali and Z. Adeel, Eds., Fate of Arsenic in the Environment, ITN Centre, BUET, Dhaka, Bangladesh, 2003, pp. 69-84.

[11] S. Roy, Z. Parveen and S. M. I. Huq, "Effect of Arsenic on the Nutrient Uptake Pattern of Amaranthus," Dhaka University Journal of Biological Sciences, Vol. 21, No. 1, 2012, pp. 87-96.

[12] M. J. Abedin, J. Cotter-Howells and A. A. Meharg, "Arsenic Uptake and Accumulation in rice (Oryza sativa L.) Irrigated with Contaminated Water," Plant and Soil, Vol. 240, No. 2, 2002, pp. 311-319. http://dx.doi.org/10.1023/A:1015792723288

[13] S. R. Molla, N. Kitajima, R. Sugawara, T. Kondo, S. M. I. Huq and S. Kawai, "Physiological and Mineralogical Properties of Arsenic-Induced Chlorosis in Barley Seedlings Grown Hydroponically," Journal of Plant Nutrition, Vol. 31, No. 2, 2008, pp. 333-353. http://dx.doi.org/10.1080/01904160701854074

[14] S. M. I. Huq, K. Parvin, S. Rahman and J. C. Joardar, "Response of Cowpea (Vigna sinensis L.) to Arsenic," Canadian Journal of Pure and Applied Sciences, Vol. 3, No. 3, 2009, pp. 897-902.
[15] M. J. Abedin, J. Feldman and A. Meharg, "Uptake Kinetics of Arsenic Species in Rice (Oryza sativa L.) Plants," Plant Physiology, Vol. 128, 2002, pp. 1120-1128. http://dx.doi.org/10.1104/pp.010733

[16] B. M. Dahal, M. Fuerhacker, A. Mentler, K. B. Karki, R. Shrestha and W. E. Blum, "Arsenic Contamination of Soils and Agricultural Plants through Irrigation Water in Nepal," Environmental Pollution, Vol. 155, No. 1, 2008, pp. 157-163. http://dx.doi.org/10.1016/j.envpol.2007.10.024

[17] S. M. I. Huq, U. K. Shila and J. C. Joardar, “Arsenic Mitigation Strategy for Rice, Using Water Regime Management," Land Contamination \& Reclamation, Vol. 14, No. 4, 2006, pp. 805-813. http://dx.doi.org/10.2462/09670513.798

[18] F. J. Zhao, J. F. Ma, A. A. Meharg and S. P. McGrath, "Arsenic Uptake and Metabolism in Plants," New Phytologist, Vol. 181, No. 4, 2009, pp. 777-794. http://dx.doi.org/10.1111/j.1469-8137.2008.02716.x

[19] Y. Hu, , J. H. Li, Y. G. Zhu, Y. Z. Huang, H. Q. Hu and P. Christie, "Sequestration of As by Iron Plaque on the Roots of Three Rice (Oryza sativa L.) Cultivars in a Low-P Soil with or without P Fertilizer," Environmental Geochemistry and Health, Vol. 27, No. 2, 2005, pp. 169176. http://dx.doi.org/10.1007/s10653-005-0132-5

[20] A. A. Meharg and M. R. Macnair, "An Altered Phosphate Uptake System in Arsenate-Tolerant Holcus lanatus L.," New Phytologist, Vol. 116, No. 1, 1990, pp. 29-35. http://dx.doi.org/10.1111/j.1469-8137.1990.tb00507.x

[21] S. R. Molla, N. Kitajima, R. Sugawara, T. Kondo, S. M. I. Huq and S. Kawai, "Physiological and Mineralogical Properties of Arsenic-Induced Chlorosis in Rice Seedlings Grown Hydroponically," Soil Science and Plant Nutrition, Vo. 52, No. 6, 2006, pp. 691-700. http://dx.doi.org/10.1111/j.1747-0765.2006.00085.x

[22] A. R. Marin, S. R. Pezeski, P. H. Masscheleyn and H. S. Choi, "Effect of Dimethyl Arsenic Acid (DMAA) on Growth, Tissue Arsenic, and Photosynthesis of Rice Plants," Journal of Plant Nutrition, Vol. 16, No. 5, 1993, pp. 865-880. http://dx.doi.org/10.1080/01904169309364580 